\title{
ТРУДОВЫЕ МИГРАНТЫ ИЗ ЦЕНТРАЛЬНОЙ АЗИИ В СИБИРСКОМ ГОРОДЕ: ИНФРАСТРУКТУРА, ЗАНЯТОСТЬ, ПОВСЕДНЕВНОСТЬ, ДОСУГ
}

\author{
ДИАНА БРЯЗГИНА, СЕИЛЬ ДЖАНЫЗАКОВА, ИРАИДА (ИРИНА) НАМ, \\ АНТОН САДЫРИН, ФЕДОР СМЕТАНИН
}

В статье представлень результаты первого года реализачии исследовательского проекта «Использование и создание мигрантами городской инфраструктуры сибирских региональных столиц» (томский кейс). В качестве объекта исследования были выбраны мигранты из трех центральноазиатских республик (Киргизия, Таджикистан и Узбекистан) как наиболее многочисленная группа иностранщев, въезжающих на территорию Томска. Выходиы из этих государств наиболее подвержень дискриминации в силу своей «видимости», а СМИ зачастую навязывают этим людям ярльк «усредненного» мигранта, несущего безусловную угрозу российскому обществу. В статье анализируются и описываются траектории социально-экономической и культурной адаптации/интеграции мигрантов 8 городе Томск. В основу исследования был положен подход, используюшийся в культурной географии, согласно которому в городском пространстве сущзествуют как традиционные (реальные), так $u$ ментальные (вернакулярные) районы, а основными критериями выделения вернакулярного района служит его локализация в восприятии жителями отдельной городской территории. Для исследования были выделены три вернакулярных района, имеющих разные соичально-экономические и географические характеристики: «Центр» как «благополучный» район, «Черемошники» как «проблемный», «Иркутчи» как «промежуточный». Основными методами сбора полевых данных послужили качественные методы: интервью и соучаствующее наблюдение. С иелью выявления элементов «мигрантской» инфраструктурь был проведен анкетный опрос мигрантов в каждом из выделенных вернакулярных районов города. Это первое исследование, направленное на понимание того, как мигранты встраиваются в экономику и социальные связи в сибирском городе. Объекты «мигрантской» инфраструктуры анализируются не как отдельные элементы экономической и сочиальной инфраструктуры, а как точки взаимодействия разных групп мигрантов и горожан. Исследуется, как эти объекты встроены в жизнь города. Оченивается степень интеграции мигрантов в городское пространство и роль соџиальных институтов, значимых для них.

Ключевые слова: трудовые мигранты, Центральная Азия, инфраструктура, занятость, повседневность, досуг, Томск.

\section{ВВЕДЕНИЕ}

Расширение трансграничных миграционных потоков и усложнение их структуры приводит к появлению новых моделей взаимодействия мигрантов с городом.

ДИАНА ЕВГЕНЬЕВНА БРЯЗГИНА (br.diana21@gmail.com), НАЦИОНАЛЬНЫЙ ИССЛЕДОВАТЕЛЬСКИЙ ТОМСКИЙ ГОСУДАРСТВЕННЫЙ УНИВЕРСИТЕТ, РОССИЯ.

СЕИЛЬ ДАВЛЕТОВНА ДЖАНЫЗАКОВА (seildzhanyzakova@gmail.com), НАЦИОНАЛЬНЫЙ ИССЛЕДОВАТЕЛЬСКИЙ ТОМСКИЙ ГОСУДАРСТВЕННЫЙ УНИВЕРСИТЕТ, РОССИЯ.

ИРАИДА (ИРИНА) ВЛАДИМИРОВНА НАМ (namirina@bk.ru), НАЦИОНАЛЬНЫЙ ИССЛЕДОВАТЕЛЬСКИЙ ТОМСКИЙ ГОСУДАРСТВЕННЫЙ УНИВЕРСИТЕТ, РОССИЯ.

АНТОН АЛЕКСЕЕВИч САДЫРИН (sadyrin.1994@mail.ru), НАЦИОНАЛЬНЫЙ ИССЛЕДОВАТЕЛЬСКИЙ ТОМСКИЙ ГОСУДАРСТВЕННЫЙ УНИВЕРСИТЕТ, РОССИЯ.

ФЕДОР АНАТОЛЬЕВИЧ СМЕТАНИН (f-smetanin@mail.ru), НАЦИОНАЛЬНЫЙ ИССЛЕДОВАТЕЛЬСКИЙ ТОМСКИЙ ГОСУДАРСТВЕННЫЙ УНИВЕРСИТЕТ, РОССИЯ.

ИССЛЕДОВАНИЕ ВЫПОЛНЕНО ПРИ ФИНАНСОВОЙ ПОДДЕРЖКЕ РНФ В РАМКАХ НАУЧНОГО ПРОЕКТА №18-18-00293 «ИСПОЛЬЗОВАНИЕ И СОЗДАНИЕ МИГРАНТАМИ ГОРОДСКОЙ ИНФРАСТРУКТУРЫ СИБИРСКИХ РЕГИОНАЛЬНЫХ СТОЛИЦ». СТАТЬЯ ПОСТУПИЛА В РЕДАКЦИЮ В НОЯБРЕ 2019 Г. 
Место жительства мигрантов, использование ими городской и/или создание собственной инфраструктуры влияют на возможности их быстрого или же, наоборот, медленного вхождения в принимающее общество. Недостаточная изученность проблемы адаптации мигрантов в городской среде, их взаимодействия с городским пространством и местными сообществами влечет за собой распространение в академических текстах и во властной риторике, в СМИ и в городской повседневности алармистского подхода к миграционной проблематике. В публичном дискурсе широко распространены представления о формирующихся этнически однородных городских районах («гетто», «чайнатаунах», «анклавах»), которые, с одной стороны, рассматриваются как угроза, с другой - как возможное решение мигрантского вопроса (Дятлов 2008).

Однако ситуация в российских городах существенно отличается от той, которую можно наблюдать в других странах, как показывают исследования, проведенные на примере Санкт-Петербурга и Москвы (Бредникова, Ткач 2010; 2012; Вендина 2009; Деминцева, Пешкова 2014; Demintseva 2017). Структура постсоветского города не позволяет выделять собственную территорию тем или иным категориям жителей. Это происходит в силу сложившейся еще в советский период застройки городов, предполагающей социальное смешение. Мигранты живут во всех районах, используя инфраструктуру экономкласса. Поэтому у мигрантов не складывается сообществ, привязанных к какой-то определенной территории (Деминцева, Пешкова 2014; Demintseva 2017). В то же время в последние годы мигранты активно создают собственную инфраструктуру, которая преимущественно ориентирована на их обслуживание. В Москве, например, появились «Киргизские клиники» (Demintseva, Kashnitsky 2018).

Использование мигрантами существующей и формирование новой городской инфраструктуры воспринимается и маркируется горожанами как «мигрантское» и/или «этническое» пространство (Дятлов 2008; Дятлов, Григоричев 2014). Однако пространства, определяемые местными жителями как «мигрантские», к которым мы можем отнести, к примеру, рынки, в действительности активно используются разными группами горожан. Создаваемая мигрантами инфраструктура часто становится точкой взаимодействия «местных» и «приезжих» (Деминцева, Пешкова 2014; Григоричев 2015), формируя пространственные связи, изменяющие характер городских мобильностей (Grigorichev 2016; Брязгина 2017).

Фокусом нашего исследования было изучение как создаваемой мигрантами, так и использования ими уже существующей инфраструктуры в сибирском городе. Как в этих местах происходит взаимодействие мигрантов с «местными»? Правомерно ли вообще говорить о существовании «мигрантской» и/или «этнической» инфраструктуры в пространстве сибирского города? При этом основная задача исследования состоит не столько в выявлении и описании объектов создаваемой и используемой мигрантами городской инфраструктуры, сколько в выяснении ее роли в жизни города и влиянии на социально-экономическую и культурную интеграцию мигрантов.

В качестве объекта исследования были выбраны трудовые мигранты из трех центрально-азиатских государств (Киргизия, Таджикистан и Узбекистан) как наиболее многочисленная группа иностранцев, въезжающих на территорию Томска и Томской 
области. Выходцы из этих государств наиболее подвержены дискриминации в силу своей «видимости», а СМИ формирует «обезличенный» образ трудового мигранта, лишенный индивидуальных человеческих черт, несущий безусловную угрозу российскому обществу (Нам и др. 2017).

\section{ТЕОРЕТИЧЕСКИЕ РАМКИ ИССЛЕДОВАНИЯ}

Теоретические исследования, направленные на изучение социально-экономической интеграции мигрантов в городе, разработаны преимущественно на примере западных городов. Одна из наиболее известных теоретических моделей, изучающих интеграцию мигрантов в городское пространство и использование ими городской инфраструктуры, теория пространственной ассимиляции (spatial assimilation), сложившаяся в середине 1980-х годов (Massey 1985). Рассматривая на примере американских городов расселение этнических меньшинств, ученые пришли к выводу, что социальный престиж зависит, в числе прочего, от места проживания человека. Некоторые обитатели «этнических кварталов» при достижении определенных экономических и социальных успехов стремятся уехать из них.

Актуальной для анализа расселения и социально-экономической интеграция мигрантов в городах России является объяснительная модель гетеролокализма (Zelinsky, Lee 1998), описывающая поведение мигрантов, которые не живут в «этнических» кварталах, но сохраняют членство в своих этнических сетях. Ее авторы Зелинский и Ли отмечают, что появление новых технологий, таких как мобильный телефон и Интернет, позволяют мигрантам жить в разных частях города, но оставаться на связи со «своей» этнической общиной (Деминцева, Пешкова 2014; Demintseva 2017). Российские города остаются социально смешанными, несмотря на условную «престижность» одних районов по сравнению с другими (Demintseva 2017; Баранова, Федорова 2017). Благодаря отсутствию привязки к какому-то району у мигрантов не складывается сообществ, привязанных к определенной территории. Наличие больших массивов социального жилья, построенного в советские годы, и существование до сегодняшнего времени коммунальных квартир в центре предоставляет мигрантам выбор места проживания (Demintseva 2017; Баранова, Федорова 2017).

Важным теоретическим инструментом исследования может быть представление о «мигрантских кластерах» как специфических социальных практиках расселения в городском пространстве культурно отличимых мигрантов, которое было положено самарскими социологами в основу изучения освоения мигрантами регионального социума. Авторы включают в содержание понятия «мигрантский кластер» объекты городского хозяйства, где наиболее активно используется труд мигрантов, примыкающие к ним жилые кварталы, в которых относительно высок удельный вес мигрантского населения, объекты инфраструктуры, которые наряду с местным населением обслуживают мигрантов. «Кластеры» формируются стихийно в силу как объективных обстоятельств (близость к работе, более доступное для съема либо приобретения в собственность жилье), так и субъективных факторов (стремление селиться и работать рядом со «своими»). Кластеры нельзя отнести ни к компактному, ни к дисперсному расселению, поскольку они 
«вкраплены» в местный поселенческий массив, постоянно пересекаются и взаимодействуют с местными локальными сообществами. В ареале одного «кластера» могут быть сосредоточены представители различных этнических групп, поэтому «кластеры»не имеют четких культурных маркеров (Мухаметшина 2014; Мухаметшина, Кандауров, Явлин 2015).

Смешанный характер постсоветского сибирского города позволяет предположить в качестве еще одной рабочей гипотезы наличие устойчивых связей, организующих дисперсно расположенную «мигрантскую» инфраструктуру города. Важнейшими узлами таких связей являются нелокализованные территориально виртуальные ядра (неформальные сети и связи - деловые, клановые, семейные, земляческие, возможно, криминальные) и формальные структуры (национально-культурные организации - НКО), которые обеспечивают как горизонтальные связи между элементами «мигрантской» инфраструктуры, так и вертикальные - взаимодействие с властными и силовыми структурами (Дятлов 2016).

\section{МЕТОДОЛОГИЯ И МЕТОДЫ ИССЛЕДОВАНИЯ}

В основу исследования был положен подход, нередко использующийся в культурной географии, согласно которому в городском пространстве существуют как традиционные (реальные), так и ментальные (вернакулярные) районы, а основными критериями их выделения служит их локализация в восприятии жителями как отдельных городских территорий (Павлюк 2007; Калуцков 2013). Вернакулярный район как единица анализа городского пространства позволяет отталкиваться в районировании города от представлений самих жителей, определяющих их восприятие города и повседневные практики. На уровне вернакулярных районов наиболее эффективным является составление ментальных карт на основе восприятия мигрантами городского пространства и картографирование элементов мигрантоориентированной инфраструктуры (Деминцева, Пешкова 2014). Использование данного подхода позволяет точнее и детальнее выяснить, как устроена в исследуемом городском пространстве мигрантоориентированная инфраструктура и какое значение для мигранта имеет «своя территория» или «свой район».

Выделение вернакулярных районов в рамках исследования основано на разнообразии их социально-экономических и географических характеристик. Основными критериями выступают как объективные признаки (стоимость аренды жилья, уровень благополучия и др.), так и субъективные представления горожан. На этих основаниях для исследования было выбрано три района: «Центр» как «благополучный» район, «Черемошники» как «проблемный», «Иркутчи» как «промежуточный». Предполагалось, что «благополучность»/«проблемность» района будет коррелировать с концентрацией в том или ином из них трудовых мигрантов и наличием/отсутствием элементов городской инфраструктуры, созданной либо освоенной приезжими.

«Центр» имеет четкие топографические и географические маркеры, определяющие его границы. С одной стороны граница района проходит по берегу р. Томь до улицы Дальне-Ключевская, с другой - по Комсомольскому проспекту до пересечения с улицей 
Елизаровых (район железнодорожного и автовокзала Томск-1), которая пересекается с улицей Нахимова (Транспортная площадь) и замыкает район в области пересечения с Московским трактом и микрорайоном Заисточье, где располагаются Красная и Белая Соборные мечети (рисунок 1). Центр города представляет собой особую локальность, отличающуюся наличием торговой и деловой зон, где концентрируется ключевая инфраструктура города (торговая, обслуживающая, транспортная и др.). «Центр» занимает обширную территорию, вытянутую вдоль центральной улицы города (проспект Ленина), и граничит с менее благоприятными с точки зрения условий жизни частями города («Черемошники»). В связи с этим жители города, проживающие в приграничной зоне, склонны сдвигать границу города далее к улицам Подгорной, Бердской, тем самым абстрагируясь от негативно маркированного восприятия городской территории.

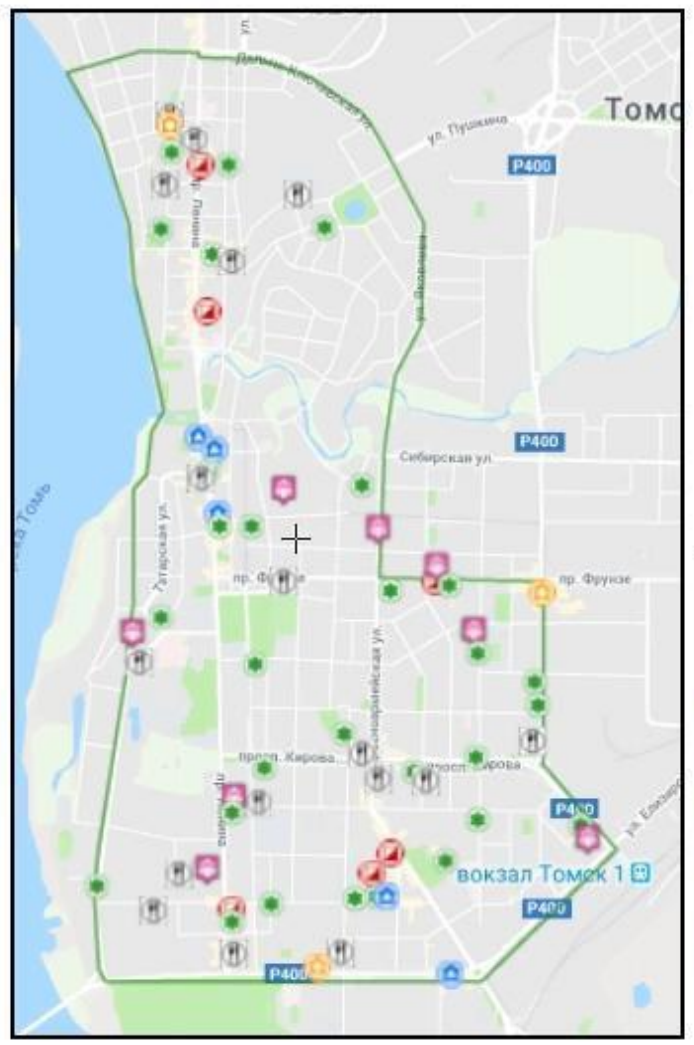

\section{Район Центр}

\begin{tabular}{|l|} 
Использование объектов \\
инфраструктуры района мигрантами \\
Рынки \\
П Продуктовые магазины \\
Магазины одежды \\
Торговые центры \\
Кафе/рестораны \\
Образовательные \\
учреждения
\end{tabular}

\section{Рисунок 1. Карта вернакулярного района «Центр»}

Источник: Материаль авторов.

Район «Черемошники» имеет условные географические рамки. С южной стороны он ограничен улицей Дальне-Ключевской, переходящей в проспект Мира. С западной стороны естественной границей служит р. Томь, на востоке район ограничен Каштачной горой (соединение проспекта Мира и улицы Смирнова). Условной северной оконечностью «Черемошников» является улица ЛПК 2-й поселок (рисунок 2). В «Черемошниках» широко распространена деревянная застройка, имеется большое количество железнодорожных развязок и переездов. Со стороны Томи располагаются крупные фабрики и заводы, такие как «Томлесдрев», «Томская домостроительная компания» и другие, что в значительной 
степени привлекает трудовых мигрантов, особенно задействованных на частных пилорамах.

Мигранты, проживающие в «Черемошниках», обосновывают выбор этого района развитой внутренней инфраструктурой, близостью к центру города и к местам работы. Основными местами, привлекающими трудовых мигрантов из стран Центральной Азии в указанном районе, являются пилорамы и овощебазы. Вокруг этих мест возникают другие немаловажные элементы «мигрантской» инфраструктуры, представленные этническими (зачастую халяльными) кафе, магазинами и парикмахерскими.

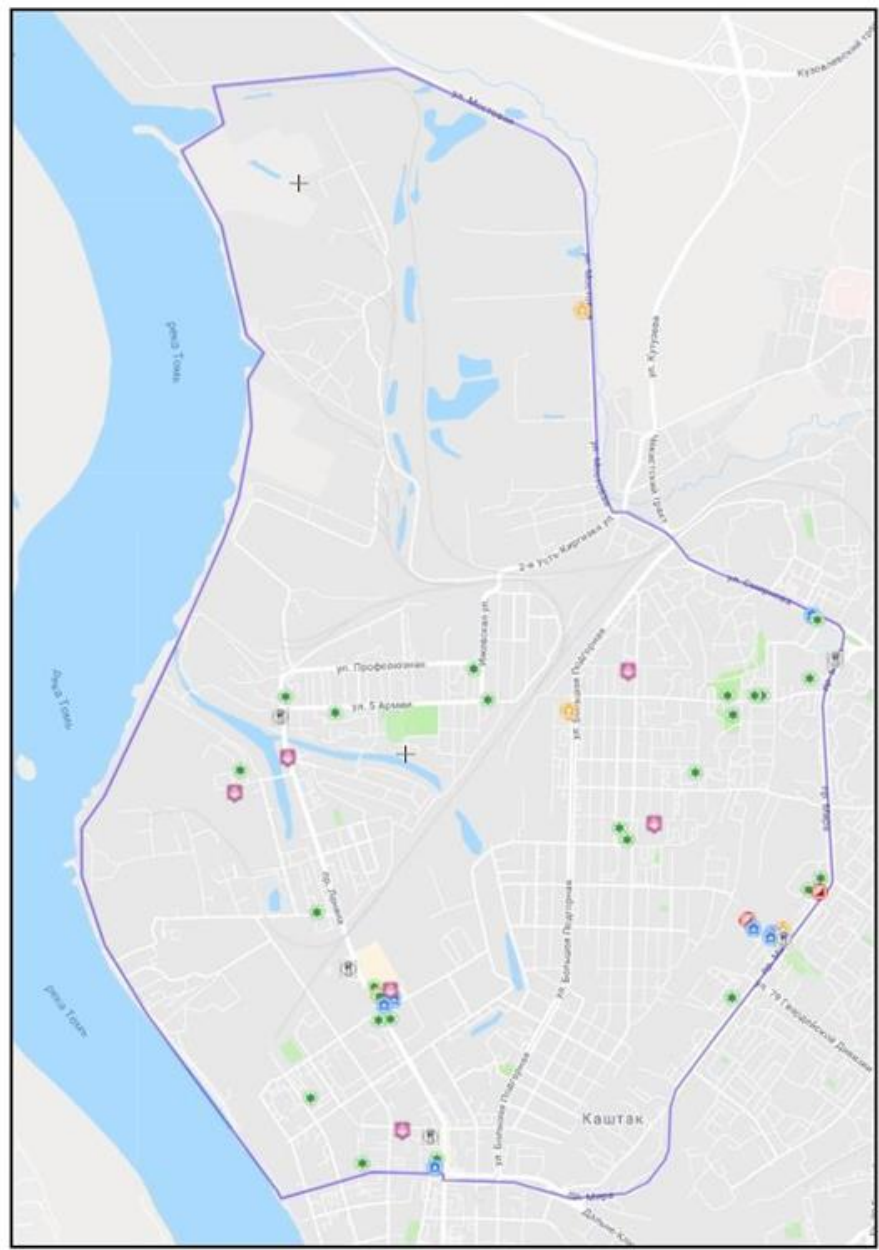

Рисунок 2. Карта вернакулярного района «Черемошники»

\section{Район Черемошники} инфраструктуры района мигрантами

\section{2) Рынки}

* Продуктовые магазины

3. Магазины одежды

(4) Торговые центры

* Кафе/рестораны

Образовательные учреждения

Источник: Материаль авторов.

Район «Иркутский» («Иркутчи») выделен как внутригородской вернакулярный район, представление о котором основано не столько на географическом делении, сколько, говоря языком урбанистов и городских географов, на концепции чувства места, наполненного социальным смыслом для человека. Основной улицей в выделенном районе является Иркутский тракт - четырехполосная широкая дорога с прилегающими по сторонам высотками и тротуарами, которая в дореволюционном Томске улицей не являлась, а была прежде всего частью проходившей через город дороги, соединяющей Дальний Восток и Сибирь с Центральной Россией. «Спальным» и доступным для широкого 
круга горожан Иркутский тракт становится во второй половине XX века, когда начинается массовая застройка этого района микрорайонами: 2-й и 3-й микрорайоны, «Солнечный», «Жилмассив» и др. Все эти микрорайоны географически связаны с улицей Иркутский тракт, образуя вернакулярный район «Иркутский» (рисунок 3).

Современные «Иркутчи» характеризуются доступностью цен на жилье, так как удалены от центра, имеют типичную советскую «спальную» застройку. Здесь находятся два крупных рынка («Октябрьский» и «Лазовский»), ведется строительство современного жилого комплекса «Ласточка», действует сеть кафе, специализирующихся на приготовлении блюд «восточной» кухни, автомоек, автомобильных сервисов, где задействованы выходцы из Центральной Азии, центров помощи в оформлении документов для мигрантов, а в начале Иркутского тракта расположен миграционный центр. Все это, на наш взгляд, способствует выбору мигрантами этого района в качестве основного места проживания, а также использованию районной инфраструктуры и созданию собственной.

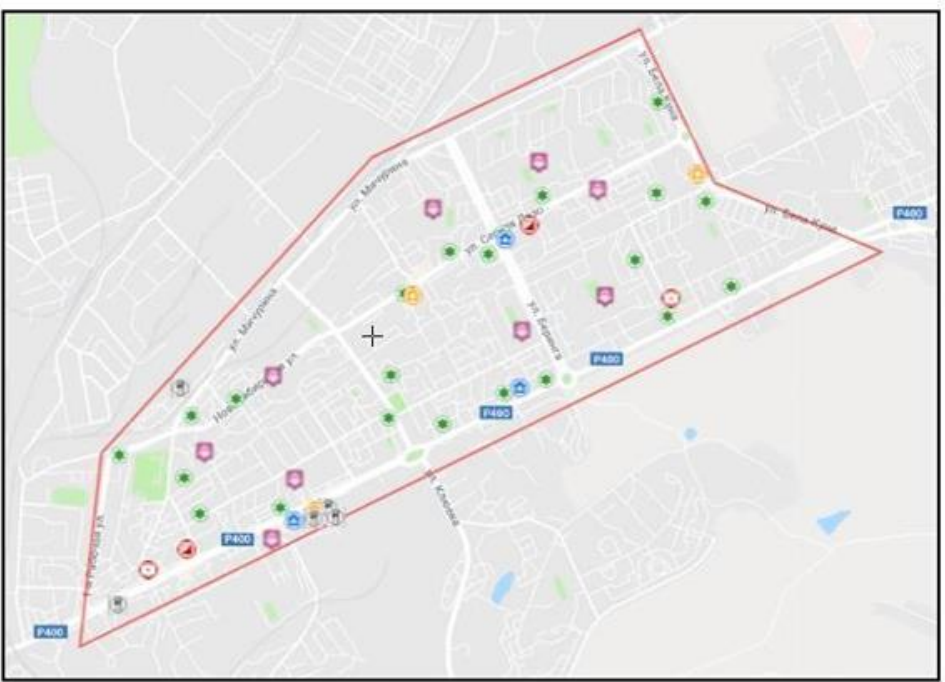

Район Иркутчи/Иркутский

Использование объектов
инфраструктуры района мигрантами

Рынки

* Продуктовые магазины

9. Магазины одежды

(9) Торговые центры

* Кафе/рестораны

- Образовательные учреждения

\section{Рисунок 3. Карта вернакулярного района «Иркутчи»}

Источник: Материалы авторов.

Полевая работа была направлена: а) на выявление городской инфраструктуры, которой пользуется мигрант в своем районе и в городе в целом; б) на изучение повседневной жизни мигранта (социальные связи, досуг, принадлежность к каким-либо сообществам). В качестве ключевых методов сбора данных в выделенных вернакулярных районах были использованы качественные методы: полуформализованные интервью и наблюдения, включая соучаствующее. Анализ интервью дает более широкий, по сравнению с анкетным опросом, спектр возможностей для получения подробной информации и уточнений со стороны респондента, что позволяет выявить специфику «мигрантской» инфраструктуры в выделенных вернакулярных районах Томска, лучше понять, как трудовые мигранты осваивают и используют пространство города и его инфраструктуру. Значительная часть интервью была проведена на рабочем месте мигрантов, что позволило увидеть обстановку и рабочий процесс в действии. Использование методологии, опирающейся на качественные исследования и внимательную этнографию, позволяет раскрыть особенности повседневной жизни мигрантов, их взаимодействия с «местными» 
жителями, выявить неформальные практики интеграции, используемые мигрантами и горожанами с учетом факторов времени и пространства.

С июля по ноябрь 2018 г. было собрано и расшифровано 60 полуформализованных интервью. Гайд интервью включал блоки вопросов, направленных на получение сведений, касающихся миграционной истории респондентов, их адаптации и опыта освоения городского пространства, повседневной жизни, жилья, досуга, взаимодействия с национально-культурными организациями и религиозными общинами.

Интервью проводили на основе анализа данных, полученных по результатам анкетного опроса, целью которого было выявление в городе мест возможной концентрации мигрантов и мигрантоориентированной инфраструктуры. Выбор анкетного опроса в качестве вспомогательного метода сбора данных в соответствии с выделенными вернакулярными районами обусловлен необходимостью формирования общей картины города, включающей не только «мигрантскую» инфраструктуру, но и другие элементы городских пространств и инфраструктуры, используемых мигрантами. Анкета состояла из вопросов, направленных на выяснение социально-демографических характеристик респондентов, сфер занятости, графика и опыта работы, использования городской инфраструктуры (магазины, рынки, транспорт, общественные пространства и др.).

Всего было опрошено 300 мигрантов по 100 человек в каждом вернакулярном районе. Выборку респондентов осуществляли на основе пропорционального распределения мигрантов, проживающих в Томске, по стране исхода. В результате было опрошено 179 выходцев из Узбекистана, 76 - из Киргизии, 45 - из Таджикистана (таблица).

Таблица. Распределение респондентов по стране происхождения (исхода)

\begin{tabular}{l|c|c}
\hline & Число, чел. & Доля, \% \\
\hline Киргизия & 76 & 25 \\
Узбекистан & 179 & 60 \\
Таджикистан & 45 & 15 \\
Всего & 300 & 100 \\
\hline
\end{tabular}

Источник: Расчеты авторов.

При этом часть опрошенных имела российское гражданство (19,3\%), что исключает этих респондентов из выборки. Однако в ходе интервью и частично в результате анкетирования было установлено, что наличие гражданства РФ дает определенные преимущества при трудоустройстве, пользовании рядом социальных услуг, но в целом не играет решающей роли в изменении или улучшении условий жизни мигрантов.

\section{КАКИЕ МИГРАНТЫ?}

По данным Управления по вопросам миграции УМВД России по Томской области, в 2018 г. на миграционный учет по месту пребывания было поставлено 72,5 тыс. человек, из которых подавляющее большинство составляют мигранты из Узбекистана (около 29 тыс.). В целом динамика миграционного прироста в Томске демонстрирует ежегодное снижение в пределах 0,5-1\% в год (Федеральная служба государственной... 2019), что отражается и в 
результатах опроса.

Из числа опрошенных наибольшее количество мигрантов прибыло в Томск в $2011-$ 2015 гг. (115 человек) и проживают в городе от 3 до 7 лет. В предыдущие 5 лет (20062010 гг.) число прибывших в 1,5 раза меньше (75 человек). За последние 2 года в Томск прибыло 65 человек из числа опрошенных (рисунок 4).

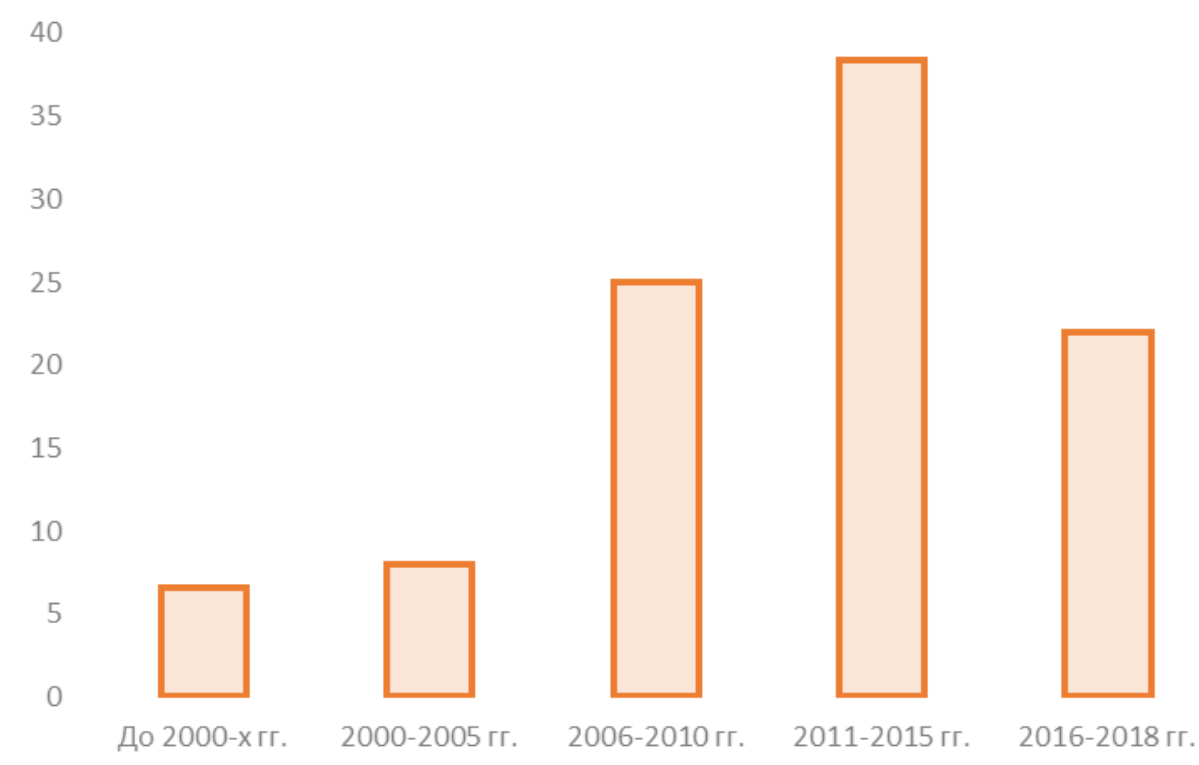

\section{Рисунок 4. Распределение респондентов по времени приезда в Томск (\%)}

Источник: Расчеты авторов.

Большинство мигрантов сохраняют тесные связи со страной исхода: около $75 \%$ опрошенных возвращаются на родину (более половины из них ездят домой раз в год или в несколько лет); некоторые уезжают домой на лето, и только $12 \%$ ни разу не возвращались домой. При этом наиболее тесные связи с родиной наблюдаются у мигрантов из Киргизии (79\%). Респондентов, имеющих двойное гражданство или статус «лицо без гражданства», в ходе интервьюирования не было выявлено. Примечательно, что выходцы из Таджикистана, получившие российский паспорт, отказались от таджикистанского гражданства.

Анализ интервью показал, что большинство трудовых мигрантов приезжают в Томск с уже имеющимся миграционным опытом, преимущественно в центральной части России (Москва, Санкт-Петербург), реже в Новосибирске, других городах: «Я приехал в 1995 г. году из Украины, я был в Харькове три года. Там (в Таджикистане) была война, после событий 1992 г. Получается, что три года жил в Харькове, это на границе с Россией, где г. Белгород. <...> Потом мне предложили: «Поехали на север, на заработки. Поехали!» Поехали так, только ненадолго, на шесть месяцев. И как приехал, так остался здесь навсегда. Вот, в 1995 начал здесь жить!» (из интервью с мужчиной из Таджикистана, 54 года).

Большое значение в жизни мигрантов, как живущих в Томске более 10-15 лет, так и (в особенности) приехавших недавно, имеют миграционные сети. Наличие родственников/земляков обусловливает как выбор города, так и первое место работы. 
При переезде в Россию происходит смена деятельности, как правило, мигранты работают не по специальности, а «где придется»:

И.: И Вы специально, получается, искали такую работу? Или в принципе?

P.: Нет, я такую не искал, просто случайно встретился с парнем из Таджсикистана. Ну он уже здесь, как говорится, гражданин России. «Где-то работа есть?» Он говорит: «Ecmь». «Ну значит, будет работать» (из интервью с мужчиной из Узбекистана, около 50 лет).

Место работы определяет и выбор места жительства в городе. Режим работы отличается высокой степенью гибкости. Интервью так же позволили зафиксировать сохраняющийся трансграничный характер трудовой миграции в Томске: все респонденты поддерживают связь со своей родиной, регулярно возвращаясь туда. Наиболее предпочтительными средствами перемещения являются самолет или автобус.

Большинство трудовых мигрантов, представляющих постсоветское поколение, имеют только среднее общее образование - 185 человек (62\%), респондентов со средним специальным и высшим образованием соответственно 21 и 14\% (рисунок 5). Среди 300 опрошенных трудовых мигрантов (мужчин и женщин) больше половины (59\%) состоят в официальном браке (178 человек). При этом среди женщин, осуществляющих трудовую деятельность в Томске, больше разведенных и вдовствующих, чем среди мужчин. $38 \%$ респондентов не имеют детей, $16 \%$ имеют одного ребенка. Наличие двух детей в семье трудового мигранта составило 25\%. Дети мигрантов представлены на всех ступенях образования от дошкольного до высшего.

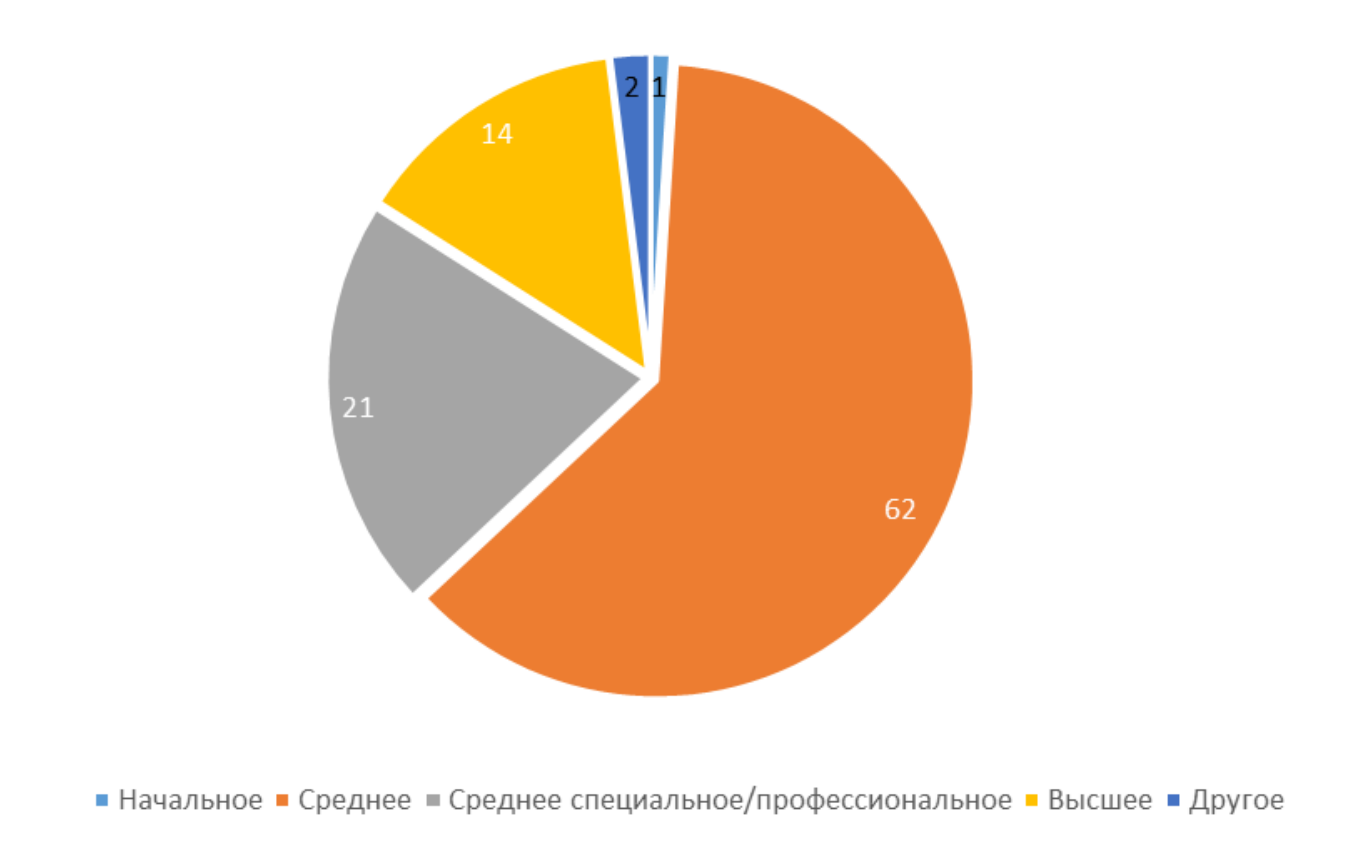

Рисунок 5. Уровень образования респондентов, \%

Источник: Расчеты авторов. 


\section{ЗАНЯТОСТЬ, ДОСУГ И ПОВСЕДНЕВНОСТЬ}

Характер трудовой деятельности мигрантов в Томске характеризуется широким разнообразием. Большинство опрошенных заняты в сфере обслуживания (51\%) и торговли (25\%). При этом в торговой отрасли мигранты представлены как в качестве продавцов, так и уборщиков, грузчиков, кладовщиков, фасовщиков и администраторов, почти $4 \%$ опрошенных имеют собственный бизнес. Наиболее распространенными местами работы мигрантов в сфере обслуживания являются объекты общепита (кафе, столовые, рестораны, бары и др.), преимущественно это заведения «восточной» либо «национальной» кухни (рисунок 6). Наибольшую долю составляют повара (сушисты, блинопеки, изготовители пиццы, шаурмы и др.) и кухонные работники разного профиля (помощники повара, заготовщики, разнорабочие и др.).
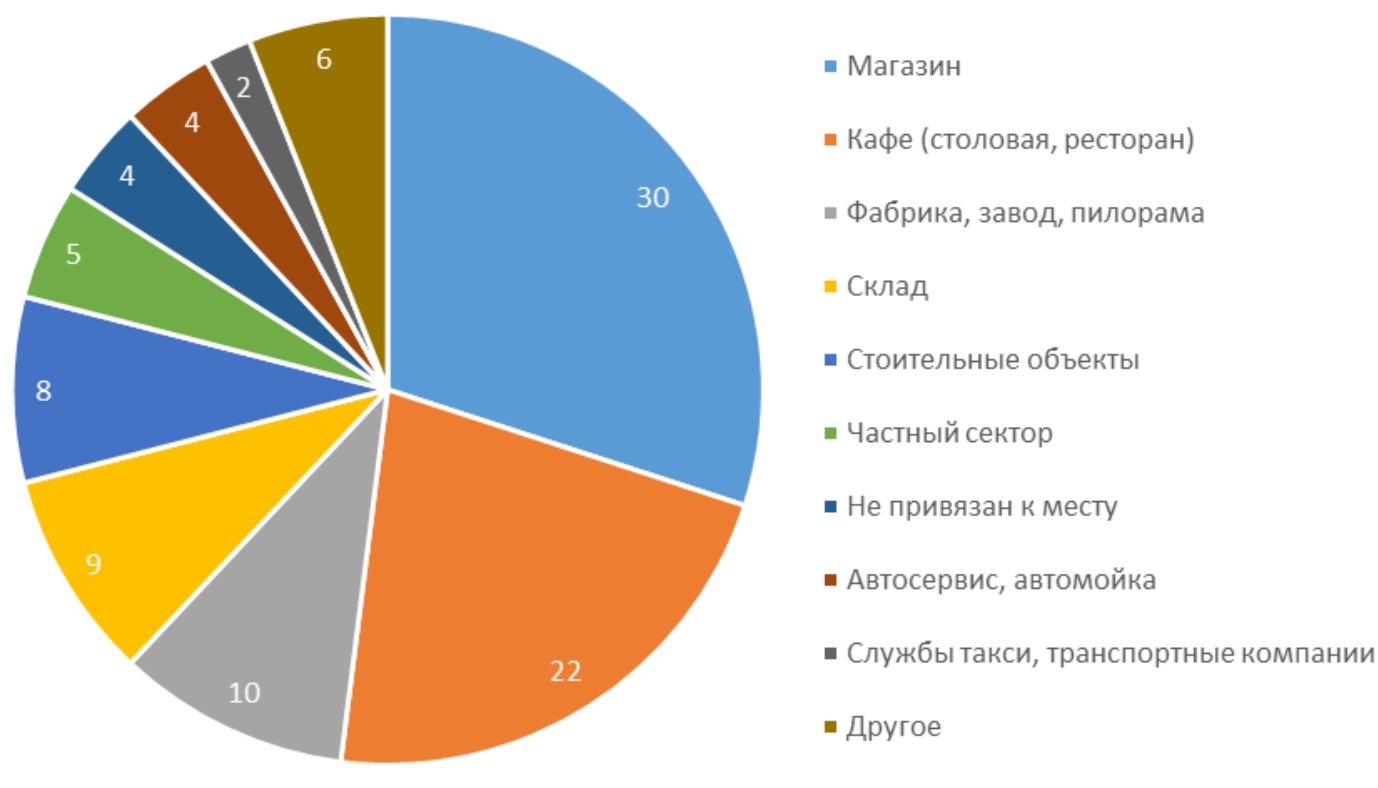

Рисунок 6. Места работы трудовых мигрантов в Томске, \%

Источник: Расчеты авторов.

Степень занятости мигрантов в Томске отличается относительной устойчивостью. Значительная доля респондентов работает в одном месте от 1 года до 5 лет (41\%). Менее одного года на одном предприятии работают $41 \%$ опрошенных, из них $25 \%$ работают в одном месте от полугода и больше, 16\% - менее 6 месяцев. Около 14\% опрошенных не меняли место работы и профессию уже более 5 лет. Наиболее устойчивые позиции занимают торговля (10\%), сфера общепита $(9 \%)$ и индивидуальное предпринимательство (5\%).

Выбор трудовой стратегии в пользу миграции обусловлен в основном низким финансовым благосостоянием семьи. Практически все опрошенные мобильны в плане изменения сферы занятости в г. Томск. Поработав, к примеру, таксистом, человек может стать поваром или даже учредителем предприятия, обзаведясь кругом единомышленников: «С четырнадиати, сразу как в Томск приехали, мы ходили по рынку и продавали чай, кофе. Потом я стал на авторынке работать, колеса вечером вытаскивали и заносили, а также 
крылья и кузовные части машин тоже стаскивали и заносили, и платили нам за это. А потом на авторынке мужик один мотоциклы ремонтировал, а когда он их мыл, я постоянно смотрел на него. И потом он позвал меня к себе работать. В итоге я там до 22-23 лет отработал «...» Я там работал механиком, а потом красить научился машины и мотоцикльл. Там просто много не заработаешь. Если только свое дело, то можно хорошо заработать. А потом брат позвал меня поваром работать. Это опять же было через знакомых, кто-то когда-то работал на кухне, хорошо заработал, открыл дело и позвал брата туда. Он устроился, поработал четыре месяча. Все выучил и меня позвал. Так мы стали работать и зарабатывать» (из интервью с мужчиной из Кирзизии, 28 лет).

Молодые мужчины-мигранты заключают официальный брак в стране-доноре во время краткосрочных поездок домой. Дети в таких семьях часто рождаются в Томске. В большинстве случаев мигрируют обратно в Россию уже с супругой.

Степень мобильности мигрантов, связанная с их трудовой деятельностью, свидетельствует о том, что место работы и место жительства чаще всего находятся в шаговой доступности относительно друг друга: около 45\% опрошенных добираются на работу пешком, причем более чем половине из них (52\%) требуется на это менее 10 минут. А половине тех, кто добирается на работу на машине (22\%), требуется на дорогу от 5 до 10 минут, следовательно, место работы мигрантов также находится недалеко от дома.

Карьерные стратегии мигрантов в Томске сложно оценить однозначно. Из 300 респондентов 142 (47,3 \%) не меняли ни профессию, ни место работы, находясь в городе. Это демонстрирует среднюю степень мобильности мигрантов в пространстве города. Около 40\% мигрантов, сменивших работу, оставались привязаны в рамках своей трудовой деятельности к району предыдущего места работы. В то же время 42\% опрошенных при смене места работы находили ее в другом районе города.

Отдыхать трудовые мигранты предпочитают дома (71\%), а при встрече с друзьями посещают кафе или гуляют по городу: в Лагерном саду (3\%), а также по торговоразвлекательному центру «Изумрудный город» $(5,7 \%)$. Выходные дни большинство опрошенных мигрантов проводят за бытовыми делами (66\%). В случае болезни половина (51\%) обращается в ближайшую муниципальную поликлинику, четвертая часть участников исследования выбирает частные клиники, около 12\% никуда не обращаются. Одним из пользующихся спросом мест встречи мигрантов является кафе «Байказан», в него ходят 4\% участников исследования. Сеть кафе «Ош», «Чинара», «Магнолия» и «Южанка», которые позиционируют себя как «восточные кухни», также пользуются спросом у мигрантов.

Продукты и одежду приезжие предпочитают приобретать в тех же магазинах и торговых сетях, что и местное население: «B районе Томск-1 есть торговый иентр «Персонал», там на втором этаже есть магазин «Zоlla», ия там все покупаю. Вот, брюки, что на мне, рубашки. Мне нравится у них и по цзенам, и по качеству» (из интервью с мужчиной из Киргизии, 32 года).

Исследование показало, что повседневность и досуг мигрантов слабо связаны с существующими в Томске конфессиональными институтами (Красной и Белой Соборными мечетями) и с национально-культурными организациями (автономиями - НКА и 
обществами - НКО). Анкетный опрос показал, что половина мигрантов не посещают мечеть, 20\% посещают мечеть только по праздникам, и только $22 \%$ - каждую неделю. При этом для многих нет особой разницы, Красная это мечеть или Белая. Зачастую критериями выбора места для совершения ритуальных практик выступают удаленность от дома и удобство расположения, принадлежность имама к той или иной этнической группе, а также знания и умение имама контактировать с мусульманами.

Опрос показал также, что лишь четвертая часть мигрантов посещает мероприятия, устраиваемые национальными организациями. Самым посещаемым является «Навруз»День весеннего равноденствия. Подавляющее большинство либо не посещают национальные мероприятия никогда $(68,3 \%)$, объясняя это нехваткой времени на досуг, либо вообще не знают о них ничего. Среди общегородских праздников, посещаемых мигрантами (25,7\%), назывались День победы, Новый год и День города, что также связано с занятостью на работе.

Исследование выявило активное пользование мигрантами социальных сетей (68\%). Наиболее популярными являются «Одноклассники» и «ВКонтакте», ими пользуются 39 и $41 \%$ соответственно. 17\% используют «Instagram», 9\% - «Facebook». 10\% опрошенных используют 3 различных ресурса и более. Широко используемыми мессенджерами для мигрантов являются WhatsUp (50\%) и Telegram (23\%). Респонденты указали также в графе «другое» Imo (15\%) - мессенджер, используемый мигрантами из Узбекистана, что связано с его популярностью в стране отправления. Основные функции, которые выполняют соцсети, - общение, знакомства, поиск и обмен информацией о соотечественниках, о месте их пребывания. При этом для поиска работы или жилья соцсети и мессенджеры практически мигрантами не используются.

\section{ЖИЛЬЕ И СОСЕДСТВО}

Значительная доля всех мигрантов, участвовавших в анкетировании, ответили, что основным видом жилья для них является квартира (90\%), лишь некоторые проживают в общежитиях (4\%) и в частных домах (6\%). В большинстве случаев «мигрантское» жилье имеет две комнаты (41\%). Наименее распространенными, но все же актуальными, являются однокомнатные жилые помещения (33\%). Есть и те, кто проживает в квартирах/домах, имеющих три комнаты и больше (15\%). Чаще всего вместе с мигрантом проживает 1-2 человека (54\%), реже - 3-4 человека (26\%). Максимальное число совместно проживающих с информантами человек равно 8 (1\%), 5-7 соседей встречаются в 4\% случаев, эта же цифра соответствует числу тех, кто проживает вовсе без кого-либо соседства. Основными соседями мигрантов являются их родственники $(76 \%)$; соседом может быть человек, с которым опрашиваемый был знаком до приезда в Россию (19\%), а также тот, с кем знакомство произошло уже здесь (14\%). Большинство мигрантов делит свою комнату еще с одним человеком (43\%). Однако немало и тех, кто в своей комнате проживает один (24\%). Часть опрашиваемых соседствуют в комнате с 2-3 людьми (28\%). С четырьмя людьми и более живут лишь 5\% опрошенных. $72 \%$ мигрантов ведут совместное хозяйство с соседями по квартире, остальные предпочитают заниматься своей экономикой в одиночку. Наиболее распространенное время, которое мигранты проживают в 
квартире/доме/общежитии на момент опроса, - от 1 года до 3 лет (около 42\%), другие ответы значительно варьируются - от нескольких дней до десятков лет.

Согласно данным, полученным в ходе интервью, часть мигрантов в Томске арендует жилье, другая часть владеет собственной недвижимостью в разных внутригородских вернакулярных районах. Зачастую определяющими факторами в разнице между мигрантами-квартиросъемщиками и собственниками выступает длительность проживания в городе, а также характер целей пребывания в Томске (кратковременные/долговременные). Среди мигрантов, арендующих жилье, в особую группу можно выделить тех, кто не платит арендную плату, а живет в квартире/доме «в счет зарплаты». В таком случае в роли главного арендатора жилья выступает хозяин бизнеса, в котором задействованы мигранты. Хозяин бизнеса/главный арендатор, помимо предоставления своим работникам жилья, нередко снабжает мигрантов продуктами, оказывает помощь при оформлении документов, а при наличии автомобиля доставляет на работу и с работы домой.

Анализируя интервью, мы пришли к выводу, что основными соседями мигранта по жилью чаще всего выступают близкие родственники, однако люди, живущие в Томске недавно, делят свой быт с теми, с кем они вместе работают. В большинстве случаев этническая принадлежность соседей мигрантов будет аналогична опрошенным мигрантам. Выбор района проживания для многих мигрантов определяется следующими обстоятельствами:

1) «историчность» района - человек старается селиться там, где когда-либо уже проживал;

2) наличие родственников в определенном районе имеет большое значение для приезжих женщин с детьми, которым порой нужна помощь близких и безопасность;

3) близость к месту работы мигранта, к тем местам, где обучаются дети, доступность инфраструктуры сильно влияет на выбор места жительства;

4) любопытен ответ участника исследования, объяснившего покупку частного дома рядом с мечетью стремлением чаще посещать храм;

5) некоторые участники исследования отмечали высокую плотность заселения районов проживания земляками, что также повлияло на их выбор жилья.

В целом в отношениях с соседями по многоквартирному дому мигранты, участвовавшие в интервью, не чувствуют себя в опасности, не отмечают возможной дискриминации по этническому признаку.

\section{КАКИЕ СТРУКТУРЫ ОКАЗЫВАЮТ ПОМОЩЬ МИГРАНТАМ?}

Ответы на вопрос, какие структуры оказывают помощь мигрантам, показали сложную и неоднозначную картину: 19,8\% респондентов назвали национальные организации/диаспоры, 13,4\% - мечети, 15,6\% - частные организации. Лидирует среди частных организаций «Мигрант-сервис» (6\%), созданная одним из основателей и лидеров НКА киргизов. Среди «других» назывались миграционные центры и сервисы $(6,7 \%)$, родственники и друзья (2,7\%). Показательно, что пятая часть опрошенных $(16,9 \%)$ дали 
отрицательные ответы на этот вопрос: «нет», «никто не помогает», «не обращался никуда».

Далеко не все мигранты знают о существовании национальных организаций («диаспор», национально-культурных автономий (НКА) и «просто» национальнокультурных организаций (НКО) в Томске). Их деятельность, связанную с оказанием помощи мигрантам, опрошенные оценивают по-разному. Одни полагают, что «диаспора» для того и создана, «чтобы кому-то чем-то помогать». Как правило, помощь мигрантам со стороны НКА и НКО выражается в разрешении конфликтных ситуаций, возникающих между трудовыми мигрантами и работодателями, между трудовыми мигрантами и властью, реже - между мигрантами и населением. Другие, напротив, полагают, что национальные организации ничем не могут, да и не стремятся помочь мигрантам. Оказать помощь могут только родственники, и в случае возникновения проблем стоит обращаться именно к ним. Некоторые информанты и вовсе негативно оценивают деятельность национальных организаций (диаспор): «Много случаев было, когда они забирают документьл и не отдают, пока человек не отработает».

И совсем небольшое число мигрантов обращается за помощью для решения тех или иных бытовых или законодательных вопросов в мечеть. Посещение мечетей сводится к отмечанию религиозных праздников и пятничному Джума-намазу.

\section{МИГРАНТЫ О ТОМСКЕ}

В представлениях мигрантов, Томск - безопасный город. На всей его территории чувствуют себя в безопасности $60 \%$ опрошенных. Не опасаются за свою жизнь и здоровье только в квартире, где проживают, 19\%, в районе проживания $-14 \%$, во дворе дома - 2\%. Лишь $2 \%$ анкетируемых не чувствуют себя в безопасности ни в одном из мест. Абсолютное большинство анкетируемых на момент опроса были уверены, что у них все в порядке с документами (84\%), но были и те, кто сомневался в том, что документы в норме (13\%).

В рассуждениях о Томске преобладает позитивное отношение к нему. Нарративы о городе можно условно разделить на несколько категорий.

1. Погодно-климатические условия: в ответах на вопросы о первом впечатлении от города респонденты отмечают суровый климат, холодную погоду, обилие снега зимой и др. Однако, несмотря на некомфортные погодные условия, негативные коннотации отсутствуют, отмечается, что со временем к такой погоде удалось привыкнуть, что условия жизни в таком климате хорошие (есть отопление в домах). Такое внимание к погоде объясняется, вероятнее всего, резкой сменой условий жизни, связанных с переездом в Томск, так как климат в странах Центральной Азии отличается гораздо более мягкими условиями и высокой температурой: «...Здесь всегда холодно, у нас просто всегда жарко, а здесь холодно, ну, все равно как привыкли, все равно дома заходите - тепло, на рынок или в магазин заходите - тепло, у нас просто иногда есть, иногда нет (тепло в домах Узбекистана - прим. авт.), домой заходите, бывает, холодно...» (из интервью с мужчиной из Узбекистана, 25 лет).

2. Городской образ жизни: здесь, чаще всего отмечаются отличия, наблюдаемые респондентами в процессе их жизнедеятельности, а именно, образ и условия жизни, 
стиль общения. Эти отличия выделяются мигрантами не на уровне этнической принадлежности, а на основе места жительства. Так, для мигрантов, переехавших из села в город, куда более значимыми оказываются особенности городской жизни: отмечаются масштабы, особенности архитектуры, отсутствие тесных социальных контактов, быстрый ритм жизни и др. Нередко проводится аналогия с городами страны исхода, но здесь различия опять же проводятся не на культурных основаниях, а по уровню экономического развития: «Томск мне нравится и даже сейчас. Первое впечатление у меня, конечно, хорочее, отночение людей другое. У них другие традици, менталитет. У нас совсем по-другому. Я из маленькой деревни приехал в большой город, конечно, мне было странно, меня восхищали многоэтажные здания, «дома-деревямки». Было сложно привыкать к дорожному движению, здесь, как тогда мне казалось, что очень было много машин. Любой на моем месте деревенский парень, так же отреагировал бы, я думаю...» (из интервью с мужчиной из Киргизии, 25 лет).

3. Экономические возможности: одним из важнейших элементов привлекательности Томска для мигрантов являются экономические условия, т. е. возможности трудоустройства, заработная плата, цены на продукты, одежду и др. Несмотря на то, что оценки экономической привлекательности Томска в нарративах мигрантов существенно отличаются, большинство подчеркивает, что конкуренция на рынке труда здесь гораздо ниже, чем в городах центральной России, цены на продукты и жилье ниже. «Мама даже говорила, чтобы я не уезжала, когда с ребенком была. А я не захотела, у меня есть гражданство, нужно здесь работать и жить, сколько есть земляков, у которых нет документов, и они работают, а я... Так вот и уехала, нужно делать и работать, встать на ноги можно здесь. Я сестре родной говорю, чтобы она сюда приехала, думала о будущем ребенка...» (из интервью с женщиной из Киргизии, 28 лет).

4. Социальные условия: наиболее значимыми для респондентов являются прежде всего толерантность принимающего общества и власти к представителям других сообществ, отсутствие постоянных рейдов и проверок со стороны контролирующих структур. Кроме того, многие респонденты отмечают, что в городе «живет много наших», что не только становится фактором привлечения мигрантов в Томск, но и облегчает процесс адаптации на первых этапах после прибытия в город: «Здесь неважно, какой ты национальности, все смотрят на тебя одинаково. Неважно, русский или нерусский. Даже если негр сюда приедет, то он именно здесь себя будет чувствовать комфортнее...» (из интервью с мужчиной из Киргизии, 28 лет).

Отношение к городу формируется не только на уровне собственного опыта проживания в Томске, но и через сравнение с пребыванием в других городах России. Чаще всего мигранты сравнивают Томск с Москвой и Новосибирском. Респонденты отмечают, что, несмотря на то, что эти города являются более привлекательными с экономической точки зрения, Томск оказывается более привлекательным по другим вышеуказанным критериям.

Примечательно, что в нарративах трудовых мигрантов отсутствует представление о городе как образовательном и научном центре. Большее внимание респонденты уделяют 
тому, что в городе в последнее время увеличилось количество строительных объектов, дороги стали лучше, построен новый торговый центр и др. Это подчеркивает степень значимости отдельных элементов городской инфраструктуры для мигрантов и указывает на то, что университеты практически никак не задействованы в этой сфере.

В целом Томск в представлении мигрантов предстает как комфортный для проживания и работы, активно развивающийся город с дружелюбным и толерантным населением. Хотя среди любимых мест в городе респонденты чаще всего называют места своего проживания, работы и близлежащие территории и объекты (двор, магазины и др.), большинство мигрантов отмечает, что в городе нет мест, где бы они чувствовали себя незащищенными.

\section{Выводы}

Анализ полевого материала, полученного в результате проведенного в 2018 г. исследования, показал, что мигранты проживают во всех трёх исследуемых вернакулярных районах, а их «благополучность» или «проблемность» не имеет прямой связи с наличием или отсутствием приезжих из Центральной Азии. Мигранты создают и используют городскую инфраструктуру преимущественно экономкласса наравне с местными жителями, посещая те же магазины, больницы, парикмахерские, что и томичи. «Мигрантская» инфраструктура распространена дисперсно в городском пространстве Томска. Использование мигрантами инфраструктуры, расположенной в других частях города, связано с нерегулярными практиками, такими как религиозные или досуговые. Это означает, что гипотеза о возможном формировании в Томске «мигрантских кластеров» на данном этапе исследования не нашла убедительного подтверждения.

Наиболее видимым в городском пространстве примером городской инфраструктуры, маркируемой как «этническая», являются кафе, представленные сетью узбекских кафе «Ош» и других «этнических» кафе: «Баракат», «Чинара». «Магнолия», «Южанка» и др. Это один из примеров создания мигрантами в городе инфраструктуры экономкласса, которая используется всеми его жителями. Трудовые мигранты также заняты в сфере обслуживания экономкласса: парикмахерских, цветочном бизнесе, мелкооптовой торговле фруктами и овощами, ремонте обуви, отделочных работах.

Важную роль в «мигрантской» инфраструктуре Томска занимают частные посреднические фирмы, предоставляющие мигрантам широкий спектр услуг, включая оформление документов на получение разрешения на временное проживание и российского гражданства, покупку российских СИМ-карт, авиабилетов и др.

Ведущим механизмом адаптации мигрантов в Томске являются родственные и земляческие сети и связи. Наличие родственников/земляков обусловливает выбор города в качестве места работы и жительства. Особое значение социальные сети и связи имеют на начальных стадиях адаптации, связанных с поиском жилья, трудоустройством, освоением города и др. 
Наконец, место национально-культурных организаций в «мигрантской» инфраструктуре города и их роль в жизни мигрантов, судя по результатам анкетного опроса и интервью, малозначительны. Организуемые национальными организациями культурные мероприятия, вопреки мнениям экспертов, не занимают ожидаемого центрального места в «мигрантском» досуге. Помощь, оказываемая национальными организациями мигрантам, не имеет для них определяющего значения. Мигранты мало осведомлены об их деятельности, путают разные структуры, общественные и частные, имеющие отношение к оказанию миграционных услуг.

\section{ЛИТЕРАТУРА}

Баранова В.В., Федорова К.С. (2017). (Не)видимость и (вне)находимость: трудовые мигранты и языковой ландшафт Санкт-Петербурга. Городские исследования и практики, 1, 103-121.

Бредникова О.Е., Ткач О.А. (2010). Дом для номады. Laboratorium, 3, 72-95.

Бредникова О.Е., Ткач О. А. (2012). Трудовые мигранты в Санкт-Петербурге: выявление проблем и выработка рекомендаций. Аналитический отчет по результатам исследования. СПб.

Брязгина Д.Е. (2017). «Китайские» рынки и городские мобильности: система общественного транспорта в повседневности города (на примере Иркутска). Сибирские исторические исследования, 1, 138-148.

Вендина О. (2009). Культурное разнообразие и «побочные» эффекты этнокультурной политики в Москве. В Иммигранты в Москве (сс. 45-147). М.: Три квадрата.

Григоричев К.В. (2015). Базар и город: «китайский» рынок как точка сборки городского пространства. В Этнические рынки в России: пространство торга и место встречи (сс. 86-105). Иркутск: Изд-во ИГУ.

Деминцева Е., Пешкова В. (2014). Мигранты из Средней Азии в Москве. Demoscope Weekly, 597-598. URL: http://www.demoscope.ru/weekly/2014/0597/tema01.php

Дятлов В.И. (2008). Россия: в предчувствии чайнатаунов. Этнографическое обозрение, 4, 6-16.

Дятлов В.И. (2016). Трансграничные мигранты в городском пространстве Сибири. В Идентификационные стратегии диаспорных и земляческих групп в российских регионах (сс. 172-173). М.: Новый Хронограф.

Дятлов В.И., Григоричев К.В. (2014). Сибирь: динамика этнизации городского пространства переселенческого общества. Известия Иркутского государственного университета. Серия: Политология. Религиоведение, 10, 8-19.

Калуцков В.О. (2013). О типах районов в культурной географии. Культурная $u$ гуманитарная география, 2(1), 3-9.

Мухаметшина Н.С. (2014). «Мигрантские» кластеры в социальном пространстве города. Известия Самарского научного иеетра Российской академии наук, Т. 16, 3(2), 638-642.

Мухаметшина Н.С., Кандауров С.П., Явлин Н.В. (2015). Стратегии освоения регионального сочиума мигрантами из соседних стран. Самара: Изд-во СНЦ РАН. 
Нам И.В., Карагеоргий Е.М., Ермолова А.И., Никитина Е.В. (2017). Конструирование образа трудового мигранта в региональных СМИ (на примере Томска). Сибирские исторические исследования, 1, 166-192.

Федеральная служба государственной статистики. Территориальный орган Федеральной службы государственной статистики по Томской области (2019). Основные демографические показатели. URL: https://tmsk.gks.ru/folder/32175

Павлюк С.Г. (2007). Традиционные и исторические районы как форма территориальной самоорганизащии общества: на примере США и России. (Автореф. дисс. канд. геогр. Наук). М.: МГУ им. М.В. Ломоносова.

Demintseva E. (2017). Labour Migrants in Post-Soviet Moscow: Patterns of Settlement. Journal of Ethnic and Migration Studies, 43(15), 2556-2572.

Demintseva E., Kashnitsky D. (2018). "Kyrgyz Clinics" in Moscow: Medical Centres for Central Asian Migrants. Medical Anthropology: Cross Cultural Studies in Health and Illness, 37(5), 401-411.

Grigorichev K.V. (2016). Migrant Localities: "Gated Spaces" or "Access Points"? Journal of Siberian Federal University. Humanities \& Social Sciences, 9, 783-794.

Massey D.S. (1985). Ethnic Residential Segregation: A Theoretical Synthesis and Empirical Review. Sociology and Social Research, 69, 315-350.

Zelinsky W., Lee B. (1998). Heterolocalism: An alternative model of the sociospatial behaviour of immigrant ethnic communities. International Journal of Population Geography, 4, 281298. 


\title{
MIGRANT WORKERS FROM CENTRAL ASIA IN A SIBERIAN \\ CITY: INFRASTRUCTURE, EMPLOYMENT, EVERYDAY LIFE AND LEISURE
}

\author{
DIANA BRYAZGINA, SEIL DZHANYZAKOVA, IRAIDA (IRINA) NAM, \\ ANTON SADYRIN, FEDOR SMETANIN
}

\begin{abstract}
This paper presents the first year results of the research project named "The Use and Creation of Urban Infrastructures by Migrants in Siberian Regional Centres" (the case of Tomsk). As the object of the study, migrants from three Central Asian republics (Kyrgyzstan, Tajikistan and Uzbekistan) were selected, as being the largest group of foreigners to come to Tomsk. Due to their "visibility", immigrants from these states are highly discriminated against and frequently labeled by the media as an "average" migrant posing a definite threat for Russian society. This article describes and analyzes the trajectories of the social, economic and cultural adaptation/integration of migrants in Tomsk. The basic approach of this study is borrowed from cultural geography, the gist being that every urban space includes both traditional (real) and mental (vernacular) areas. The main criterion for distinguishing a vernacular area is its localization in the perception by residents of a particular urban area. Three vernacular districts with different socio-economic and geographical characteristics were identified for the study: "The center", a "prosperous" district, "Cheremoshniki", a "problematic" district, and "Irkutchi", an "intermediate" district. The main tools for collecting field data were interviews and participant observation. A survey of migrant workers in each of the vernacular areas was used as an additional method. This is the first study aimed at understanding how migrants integrate into the economy and social relations in a Siberian city. The objects of the "migrant" infrastructure are analyzed not as separate elements of the economic and social infrastructure, but as points of interaction between different groups of migrants and citizens. The paper explores how these objects are embedded into the life of the city and evaluates the degree of integration of migrants in urban space and the role of social institutions that are significant for them.
\end{abstract}

Key words: migrant workers, Central Asia, infrastructures, employment, everyday life, leisure, Tomsk.

DiANa BRYAZgina (br.diana21@gmail.com), NATIONAL RESEARCH TOMSK STATE UNIVERSity, RusSiA.

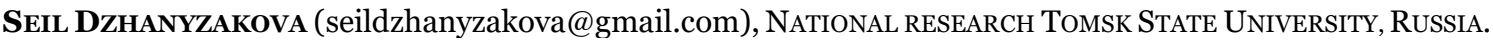

Iraida (Irina) NAM (namirina@bk.ru), NATIONAL RESEARCh Tomsk State University, RusSia.

ANTON SADYRIN (sadyrin.1994@mail.ru), NATIONAL RESEARCh ToMsk STATE University, RUSSIA.

Fedor SMetanin (f-smetanin@mail.ru), National RESEArCh Tomsk State University, Russia.

THE STUDY WAS CARRIED OUT WITH THE FINANCIAL SUPPORT OF THE RUSSIAN SCIENCE FOUNDATION IN THE FRAMEWORK OF THE SCIENTIFIC PROJECT NO. 18-18-0O293 «THE USE AND CREATION OF URBAN INFRASTRUCTURES BY MIGRANTS IN SibERIAN ReGiONAL CENTRES».

DATE RECEIVED : NOVEMBER 2019.

\section{REFERENCES}

Baranova V.V., Fjodorova K.S. (2017). (Ne)vidimost' i (vne)nakhodimost': trudovyye migranty i yazykovoy landshaft Sankt-Peterburga [(In)visiability and (non)existence: labor migrants and St. Petersburg linguistic landscape]. Urban Studies and Practices, 1, 103-121 (In Russ.). 
Brednikova O.E., Tkach O.A. (2010). Dom dlya nomady [What home means to the nomad]. Laboratorium, 3, 72-95. (In Russ.).

Brednikova O.E., Tkach O.A. (2012). Trudovyye migranty v Sankt-Peterburge: vyyavleniye problem i vyrabotka rekomendatsiy [Labor migrants in St. Petersburg: identifying problems and making recommendations]. Analytical Research Report. St. Petersburg. (In Russ.).

Bryazgina D.E. (2017). «Kitayskiye» rynki i gorodskiye mobil'nosti: sistema obshchestvennogo transporta $v$ povsednevnosti goroda (na primere Irkutska) ["Chinese" markets and urban mobilities: public transport system in everyday life in the city (the case of Irkutsk)]. Siberian Historical Research, 1, 138-148. (In Russ.).

Demintseva E. (2017). Labour Migrants in Post-Soviet Moscow: Patterns of Settlement. Journal of Ethnic and Migration Studies, 43(15), 2556-2572.

Demintseva E., Kashnitsky D. (2018). "Kyrgyz Clinics" in Moscow: Medical Centres for Central Asian Migrants. Medical Anthropology: Cross Cultural Studies in Health and Illness, 37(5), 401-411.

Demintseva E., Peshkova V. (2014). Migranty iz Srednej Azii v Moskve [Central Asian migrants in Moscow]. Demoscope Weekly, 597- 598. URL:

http://www.demoscope.ru/weekly/2014/0597/tema01.php (In Russ.).

Dyatlov V.I. (2008). Rossiya: v predchuvstvii chaynataunov [Russia: in anticipation of Chinatowns]. Etnograficheskoe obozrenie, 4, 6-16. (In Russ.).

Dyatlov V.I. (2016). Transgranichnyye migranty v gorodskom prostranstve Sibiri [Cross-border migrants in Siberian urban space]. In Identifikatsionnyye strategii diaspornykh i zemlyacheskikh grupp v rossiyskikh regionakh [Identification strategies of diaspora and compatriot groups in Russian regions] (pp. 172-173). Moscow: New Chronograph. (In Russ.).

Dyatlov V.I., Grigorichev K.V. (2014). Sibir': dinamika etnizatsii gorodskogo prostranstva pereselencheskogo obshchestva [Siberia: dynamics of urban space ethnicization in the resettlement society]. The bulletin of Irkutsk State Univercity. Series: Political Science and Religious Studies 10, 8-19 (In Russ.).

Grigorichev K.V. (2015). Bazar i gorod: "kitajskij" rynki kak tochka sborki gorodskogo prostranstva [The bazaar and the city: "Chinese" market as the assemblage point of the city]. Etnicheskie rynki $v$ Rossii: prostranstvo torga i mesto vstrechi [Ethnic markets in Russia: space of bargaining and place of meeting]. Irkutsk: Izdatel'stvo IGU. (In Russ.).

Grigorichev K.V. (2016). Migrant Localities: "Gated Spaces" or "Access Points"? Journal of Siberian Federal University. Humanities \& Social Sciences, 9, 783-794.

Kaluckov V.O. (2013). O tipakh rayonov v kul'turnoy geografii [About types of districts in cultural geography]. Cultural Geography \& Geohumanities, 2(1), 3-9. (In Russ.).

Massey D.S. (1985). Ethnic Residential Segregation: A Theoretical Synthesis and Empirical Review. Sociology and Social Research, 69, 315-350.

Muhametshina N.S. (2014). «Migrantskiye» klastery v sotsial'nom prostranstve goroda ["Migrant clasters" in urban space]. Izvestiya of Samara Scientific Center of the Russian Academy of Sciences, Vol. 16, 3(2), 638-642. (In Russ.).

Muhametshina N.S., Kandaurov S.P., Yavlin N.V. (2015). Strategii osvoyeniya regional'nogo sotsiuma migrantami iz sosednikh stran [Development Strategies of regional society by migrants from neighboring countries]. Samara: Izdatel'stvo SNTS RAN. (In Russ.). 
Nam I.V., Karageorgij E.M., Ermolova A.I., Nikitina E.V. (2017). Konstruirovaniye obraza trudovogo migranta $\mathrm{v}$ regional'nykh SMI (na primere Tomska) [The image of labor migrants constructed by the mass media: the case of Tomsk]. Siberian Historical Research, 1, 166-192 (In Russ.).

Federal State Statistics Service. Regional Statistics Office of Federal State Statistics Service in Tomsk Region (2019). Osnovnyye demograficheskiye pokazateli [The main demographic indicators]. URL: https://tmsk.gks.ru/folder/32175_(In Russ.).

Pavljuk S.G. (2007). Traditsionnyye i istoricheskiye rayony kak forma territorial'noy samoorganizatsii obshchestva: na primere SSHA $i$ Rossii [Traditional and historical areas as a form of territorial self-organization of society: case of the USA and Russia]. (PhD Thesis). Moscow: Lomonosov Moscow State University. (In Russ.).

Vendina O. (2009). Kul'turnoye raznoobraziye i «pobochnyye» effekty etnokul'turnoy politiki v Moskve [Cultural diversity and "secondary" effects of ethnocultural policy in Moscow]. In Immigranty v Moskve [Immigrants in Moscow] (pp. 45-147). Moscow: Three Foursquares. (In Russ.).

Zelinsky W., Lee B. (1998). Heterolocalism: An alternative model of the sociospatial behaviour of immigrant ethnic communities. International Journal of Population Geography, 4, 281 298. 